\title{
Synthesis and evaluation of arylamidine derivatives for new antimicrobial and cytotoxic activities
}

\author{
ZENAIDE S. MONTE ${ }^{1}$, AMANDA M. SILVA ${ }^{2}$, GLÁUCIA M.S. LIMA ${ }^{3}$, TERESINHA G. DA SILVA ${ }^{3}$, KARLA \\ M.R. MARQUES ${ }^{3}$, MARIA D. RODRIGUES ${ }^{3}$, EMERSON P.S. FALCÃ ${ }^{4}$ and SEBASTIÃO J. MELO ${ }^{1}$
}

\author{
${ }^{1}$ Programa de Pós-Graduação em Ciências Farmacêuticas, Departamento de Ciências Farmacêuticas, Universidade \\ Federal de Pernambuco/UFPE, Av. Prof. Moraes Rego, 1235, Cidade Universitária, 50740-560 Recife, PE, Brazil \\ ${ }^{2}$ Departamento de Biomedicina, Universidade Federal de Pernambuco/UFPE, Av. Prof. \\ Moraes Rego, 1235, Cidade Universitária, 50740-560 Recife, PE, Brazil \\ ${ }^{3}$ Departamento de Antibióticos, Universidade Federal de Pernambuco/UFPE, Av. Prof. \\ Moraes Rego, 1235, Cidade Universitária, 50740-560 Recife, PE, Brazil \\ ${ }^{4}$ Departamento de Nutrição, Núcleo de Nutrição da Universidade Federal de Pernambuco (CAV - UFPE), \\ Rua Alto do Reservatório, Bela Vista, s/n, 55608-680 Cidade Vitoria de Santo Antão, PE, Brazil
}

Manuscript received on November 17, 2016; accepted for publication on December 5, 2016

\begin{abstract}
A series of arylamidines 3a-j was designed, synthesized and investigated for antimicrobial activity. Structures of the compounds were confirmed by IR, ${ }^{1} \mathrm{H}-\mathrm{NMR}$ and ${ }^{13} \mathrm{C}-\mathrm{NMR}$ and a $2 \mathrm{D}$ spectroscopic study was performed. A preliminary screening of the antimicrobial tests clearly showed that three out of ten arylamidines, viz, $\mathbf{3} \mathbf{f}, \mathbf{3} \mathbf{g}$ and $\mathbf{3 i}$, were effective against all the gram-negative bacteria: Klebsiella pneumoniae, Pseudomonas aeruginosa and Salmonella enteric; and against the yeast, candida albicans. Further, the Minimum Inhibitory Concentrations (MIC) against the bacteria and yeast were determined. All compounds $\mathbf{3 a - d}, \mathbf{3 f}, \mathbf{3 g}, \mathbf{3 i}$ and $\mathbf{3 j}$ were also investigated for their low cytotoxic effects on tested cell lines. Compounds $\mathbf{3 d}$ and $\mathbf{3 f}$ were the most effective derivatives against HL-60 and HEp-2 cells, respectively, with $\mathrm{IC}_{50}$ value $(2 \mu \mathrm{g} / \mathrm{mL})$, and low normal cells toxicity.
\end{abstract}

Key words: arylamidines, 2D spectroscopy, gram-negative bacteria, yeast, cytotoxicity.

\section{INTRODUCTION}

Amidine is an integral part of the chemical structure of the pyrimidine and pyrimidinone class of compounds, having a range of pharmacological activities: anti-inflammatory (Falcão et al. 2006, Natarajan et al. 2014) anticonvulsant (Samuel et al. 2016), antitumor (Marzano et al. 2010),

Correspondence to: Sebastião José de Melo

E-mail: melosebastiao@yahoo.com.br antimicrobial (Pizzuti 2005) and anticarciogenic (Makarov et al. 2005), antiviral (Andrews and Mansur 2014), antibacterial (Arafa et al. 2005), and antiprotozoal (Adiyala et al. 2014). A chemical interest in amidine derivatives is also reported in the literature. The synthesis of a series of 31 $\alpha$-amino amidines derived from the reaction of aromatic aldehydes, aromatic amines and isonitrile and nitriles carried out using molecular iodine as 
the catalyst (Tahghighi et al. 2011). Tahghighi et al. (2011) conducted a synthesis of 10 amidine derivatives and determined their antileishmanial activity against the promastigote form of L. major, of which three products showed promising results (Asano et al. 2004) Driven by the chemical similarity of amidines with the 4-anilinoquinazolines that inhibit the epidermal growth factor receptor (EGFR) tyrosine kinase (Melo et al. 2002), we synthesized two benzamidines and found that they strongly inhibit tyrosine EGFR kinase. Our research group has been synthesizing amidines derivatives for the past 30 years. Numerous pyrimidine derivatives (Falcão et al. 2006, Francisco 2007, Do Monte et al. 2016) containing amidines as part of their structures, have shown us promising results with their antiinflammatory, anticonvulsant, anti-tumor and antimicrobial activity. The literature also has reports on the pharmacological potential of amidines. So, considering that their antimicrobial properties have not been reported in the literature, we evaluated the antimicrobial activities of 10 arylamidine, 08 of which had been obtained by our research group previously (Falcão et al. 2006, Francisco 2007, Do Monte et al. 2016). We also conducted a one- and two-dimensional nuclear magnetic resonance study for the compound 4-nitrobenzimidamide.

\section{MATERIALS AND METHODS}

\section{MATERIALS AND INSTRUMENTS}

All reagents were obtained from commercial (Sigma-Aldrich) sources and used without further purification. All melting points were recorded on a BUCHI B-540 apparatus and were not corrected. The IR spectra were recorded on a Perkin Elmer Spectrum 400, using the $\mathrm{KBr}$ wafer technique. The spectra of compound 3a-j were acquired using a VARIAN Unity Plus 300 spectrometer operating at $300 \mathrm{MHz}$ and $75 \mathrm{MHz}$ for ${ }^{1} \mathrm{H}$ and ${ }^{13} \mathrm{C}$ nuclei, respectively. Reactions were monitoring by thin layer chromatography (TLC) with precoated silica gel on aluminum sheets (60 mesh containing fluorescent indicator $\mathrm{F}_{254}$, Merck). Visualization of the spots was carried out under ultraviolet light (UV) at 365 and $254 \mathrm{~nm}$.

\section{SYNTHESIS}

Preparation of derivative arylamidine, 3a-j: An appropriate amount of bisnitrile (42.86 mmol) 1a-g was dissolved in ethanol grade for HPLC $(10 \mathrm{~mL})$ and refluxed for 4 hours at room temperature in the presence of Hydrochloric acid gas. Gas ammonia was added to the then formed intermediate imidate, then refluxed, for 2 hours while the solution was maintained in an ice bath. After the reaction was completed, the solvent evaporated to give a solid mass, which was crystallized and recrystallized with solvent $n$-pentane to generate the corresponding arylamidine. The data for $\mathbf{3 b} \mathbf{b} \mathbf{j}$ are described below:

\section{4-methoxybenzamidine (3b)}

This compound was obtained as colorless crystals from n-pentane in $89.90 \%$ yield, m.p. 205-207, $\mathrm{R}_{f}$ $=0$ (n-hexane-ethylacetate 8:2); IR, KBr, $\gamma_{\max } \mathrm{cm}^{-1}$ : $3107\left(\mathrm{NH}_{\text {2asymm }}\right), 3019\left(\mathrm{NH}_{2 \text { symm }}\right), 1602(\mathrm{C}=\mathrm{N})$; ${ }^{1} \mathrm{H}-\mathrm{NMR}$ (DMSO-d $6300 \mathrm{MHz}$ ), $\delta: 7.80$ (d, 2H, $J$ $9.0 \mathrm{~Hz}, \mathrm{H} 3$ and H5); 7.13 (d, 2H, $J 9.0 \mathrm{~Hz}, \mathrm{H} 2$ and H6); 5.85 (b, 2H, C7- $\mathrm{NH}_{2}$ ) and $3.89(\mathrm{~s},-\mathrm{OMe}) .{ }^{13} \mathrm{C}-$ NMR (DMSO-d $6300 \mathrm{MHz}), \delta: 166.0$ (1C, C7); 120.8 (1C, C1); 160.0 (1C, C4);131.0 (2C, C2 and C6) ; 115.8 (2C, $\mathrm{C} 3$ and $\mathrm{C} 5)$ and 56.2 (1C, -OMe).

\section{4-methylbenzamidine (3c)}

This compound was obtained as colorless crystals from n-pentane in 90\% yield, m.p. 199-201, $\mathrm{R}_{\mathrm{f}}=$ 0 (n-hexane-ethylacetate 7:3); IR, KBr, $\gamma_{\max } \mathrm{cm}^{-1}$ : $3123\left(\mathrm{NH}_{\text {2asymm }}\right), 2990\left(\mathrm{NH}_{2 \text { symm }}\right), 1676(\mathrm{C}=\mathrm{N})$; ${ }^{1}$ H-NMR (DMSO-d 600 MHz), $\delta: 7.73$ (d, 2H, J 9.0 Hz, H3 and H5); 7.43 (d, 2H, J 9.0 Hz, H2 and H6); $4.90\left(\mathrm{~b}, 2 \mathrm{H}, \mathrm{C} 7-\mathrm{NH}_{2}\right)$ and $2.45(\mathrm{~s},-\mathrm{Me}){ }_{13} \mathrm{C}-\mathrm{NMR}$ (DMSO-d6 300 MHz), $\delta: 168.2$ (1C, C7); 146.7 
(1C, C1); 131.0 (2C, C2 and C6);129.0 (2C,C3 and C5); 126.4 (1C, C4) and $21.6(1 \mathrm{C},-\mathrm{Me})$.

\section{4-diethylaminobenzamidine (3d)}

This compound was obtained as colorless crystals from n-pentane in $89 \%$ yield, m.p. 201-203, $\mathrm{R}_{\mathrm{f}}=$ 0 (n-hexane-ethylacetate 8:2); IR, KBr, $\gamma_{\max } \mathrm{cm}^{-1}$ : $3369\left(\mathrm{NH}_{\text {2asymm }}\right), 3019\left(\mathrm{NH}_{2 \text { symm }}\right), 1654(\mathrm{C}=\mathrm{N})$; ${ }^{1} \mathrm{H}-\mathrm{NMR}$ (DMSO-d $6300 \mathrm{MHz}$ ), $\delta: 8.44$ (d, 2H, J $9.0 \mathrm{~Hz}, \mathrm{H} 3$ and $\mathrm{H} 5) ; 8.06$ (d, 2H, J $9.0 \mathrm{~Hz}, \mathrm{H} 2$ and $\mathrm{H} 6) ; 5.12\left(\mathrm{~b}, 2 \mathrm{H}, \mathrm{C} 7-\mathrm{NH}_{2}\right)$ and $3.30\left(\mathrm{~s},-\mathrm{NC}_{2} \mathrm{H}_{6}\right) .{ }^{13} \mathrm{C}-$ NMR (DMSO-d6 $300 \mathrm{MHz}$ ), $\delta$ : 166.0 (1C, C7); 147.8 (1C, C1);135.0 (2C, C2 and C6); 131.8 (1C, C4); 125.3 (2C,C3 and $\mathrm{C} 5)$ and 49,0 (1C, $\left.-\mathrm{NC}_{2} \mathrm{H}_{6}\right)$.

\section{4-aminobenzamidine (3e)}

This compound was obtained as colorless crystals from n-pentane in $92.90 \%$ yield, m.p. 136-138, $\mathrm{R}_{\mathrm{f}}$ $=0$ (n-hexane-ethylacetate8:2); IR, $\mathrm{KBr}, \gamma_{\max } \mathrm{cm}^{-1}$ : $3080\left(\mathrm{NH}_{\text {2asymm }}\right), 3004\left(\mathrm{NH}_{2 \text { symm }}\right), 1659(\mathrm{C}=\mathrm{N})$; ${ }^{1} \mathrm{H}-\mathrm{NMR}$ (DMSO-d $\left.6300 \mathrm{MHz}\right), \delta: 7.80(\mathrm{~d}, 2 \mathrm{H}, \mathrm{J}$ $9.0 \mathrm{~Hz}, \mathrm{H} 3$ and H5); 7.13 (d, 2H, J 9.0 Hz, H2 and H6); 4.85 (b, 2H, C7- $\mathrm{NH}_{2}$ ) and 3.89 (s,-OMe). ${ }^{13} \mathrm{C}-$ NMR (DMSO-d6 300 MHz), $\delta: 166.0$ (1C, C7); 160.0 (1C, C1); 131.0 (2C, C2 and C6) ;120.8 (1C, $\mathrm{C} 4) ; 115.8$ (2C,C3 and $\mathrm{C} 5)$ and 56.2 (1C,-OMe).

\section{4-trifluoromethylbenzamidine (3f)}

This compound was obtained as colorless crystals from n-pentane in $82.90 \%$ yield, m.p. 215-217, $\mathrm{R}_{\mathrm{f}}$ $=0$ (n-hexane-ethylacetate 7:3); IR, KBr, $\gamma_{\max } \mathrm{cm}^{-1}$ : $3289\left(\mathrm{NH}_{\text {2asymm }}\right), 3198\left(\mathrm{NH}_{2 \text { symm }}\right), 1612(\mathrm{C}=\mathrm{N})$; ${ }^{1} \mathrm{H}-\mathrm{NMR}$ (DMSO-d $6300 \mathrm{MHz}$ ), $\delta 8.00$ (d, 2H, J 9.0 $\mathrm{Hz}, \mathrm{H} 3$ and H5); 7.09 (d, 2H, J 9.0 Hz, H2 and H6) and 4.85 (b, 2H, C7-NH ${ }_{2}$ ). ${ }^{13} \mathrm{C}-\mathrm{NMR}$ (DMSO-d6 $300 \mathrm{MHz}), \delta: 159.6$ (1C, C7); 134.5 (1C, C1);134.0 (1C, C4); 132.0 (2C, C2 and C6) ; 131.3 (2C,C3 and C5) and $128.0(1 \mathrm{C}, \mathrm{C} 8)$.

\section{4-bromomethylbenzamidine (3g)}

This compound was obtained as colorless crystals from n-pentane in 76\% yield, m.p. 203-205, $\mathrm{R}_{\mathrm{f}}=$ 0 (n-hexane-ethylacetate 8:2); IR, KBr, $\gamma_{\max } \mathrm{cm}^{-1}$ : $3213\left(\mathrm{NH}_{\text {2asymm }}\right), 3104\left(\mathrm{NH}_{2 \text { symm }}\right), 1615(\mathrm{C}=\mathrm{N})$; ${ }^{1} \mathrm{H}-\mathrm{NMR}$ (DMSO-d $300 \mathrm{MHz}$ ), $\delta 7.97$ (d, 2H, J $9.0 \mathrm{~Hz}, \mathrm{H} 3$ and H5); 7.09 (d, 2H, J $9.0 \mathrm{~Hz}, \mathrm{H} 2$ and H6) and 4.83 (b, 2H, C7-NH2); 4.70 (s, 1H, H7); ${ }^{13} \mathrm{C}-\mathrm{NMR}$ (DMSO-d6 $300 \mathrm{MHz}$ ), $\delta: 166.0$ (1C, C7) 140.6 (1C, C1); 134.2 (2C,C3 and C5); 130.1 $(2 \mathrm{C}, \mathrm{C} 2$ and C6) and $119.0(1 \mathrm{C}, \mathrm{C} 4)$.

\section{4-chlorobenzamidine (3h)}

This compound was obtained as colorless crystals from n-pentane in $90.75 \%$ yield, m.p. 219-221, $\mathrm{R}_{\mathrm{f}}$ $=0$ (n-hexane-ethylacetate 8:2); IR, $\mathrm{KBr}, \gamma_{\max } \mathrm{cm}^{-1}$ : $3092\left(\mathrm{NH}_{\text {2asymm. }}\right), 3001\left(\mathrm{NH}_{2 \text { symm }}\right), 1593(\mathrm{C}=\mathrm{N})$; ${ }^{1} \mathrm{H}-\mathrm{NMR}$ (DMSO-d $300 \mathrm{MHz}$ ), $\delta: 7.72$ (d, 2H, J9.0 $\mathrm{Hz}, \mathrm{H} 3$ and $\mathrm{H} 5$ ); 7.58 (d, 2H, J9.0 Hz, H2 and H6) and $4.84\left(\mathrm{~b}, 2 \mathrm{H}, \mathrm{C} 7-\mathrm{NH}_{2}\right) \cdot{ }^{13} \mathrm{C}-\mathrm{NMR}$ (DMSO-d $300 \mathrm{MHz}$ ), $\delta: 166.0$ (1C, C7) 140.6 (1C, C4); 134.2 (2C, C3 and C5); 130.1 (2C, C2 and C6) and 119.0 (1C, C1).

\section{2,6-dichlorobenzamidine(3i)}

This compound was obtained as colorless crystals from n-pentane in $81 \%$ yield, m.p. 225-227, $\mathrm{R}_{\mathrm{f}}=$ 0 (n-hexane-ethylacetate 8:2); IR, $\mathrm{KBr}, \gamma_{\max } \mathrm{cm}^{-1}$ : $3319\left(\mathrm{NH}_{\text {2asymm }}\right), 3114\left(\mathrm{NH}_{2 \text { symm }}\right), 1525(\mathrm{C}=\mathrm{N}) ;{ }^{1} \mathrm{H}-$ NMR (DMSO-d $300 \mathrm{MHz}), \delta$ 7.82-7.72 (m, 2H, $\mathrm{H} 5$ and $\mathrm{H} 6) ; 7.65-7.60(\mathrm{t}, \mathrm{J} 7,5 \mathrm{~Hz}, 1 \mathrm{H}, \mathrm{H} 2)$ and $4.83\left(\mathrm{~b}, 2 \mathrm{H}, \mathrm{C} 7-\mathrm{NH}_{2}\right) ;{ }^{13} \mathrm{C}-\mathrm{NMR}$ (DMSO-d 6300 $\mathrm{MHz}), \delta$ : 168.6 (1C, C7); 135.2 (1C, C3); 130.5 (1C, C2); $129.6(1 \mathrm{C}, \mathrm{C} 5) 129.0(1 \mathrm{C}, \mathrm{C} 4)$ and 123.0 $(1 \mathrm{C}, \mathrm{C} 1)$

\section{3-chlorobenzamidine (3j)}

This compound was obtained as colorless crystals from n-pentane in $66 \%$ yield, m.p. 216-218, $\mathrm{R}_{\mathrm{f}}=$ 0(n-hexane-ethylacetate8:2); IR, KBr, $\gamma_{\max } \mathrm{cm}^{-1}$ : $3424\left(\mathrm{NH}_{\text {2asymm }}\right), 3114\left(\mathrm{NH}_{2 \text { symm }}\right), 1698(\mathrm{C}=\mathrm{N}) ;{ }^{1} \mathrm{H}-$ NMR (DMSO-d $600 \mathrm{MHz}), \delta: 7.82-7.72(\mathrm{~m}, 2 \mathrm{H}$, 
$\mathrm{H} 5$ and $\mathrm{H} 6) ; 7.65-7.60$ (t, J 7.5 Hz, 1H, H2) and 4.83 (b, 2H, C7-NH $)$ ); ${ }^{13} \mathrm{C}-\mathrm{NMR}$ (DMSO-d6 300 $\mathrm{MHz}), \delta: 168.6$ (1C, C7); 135.2 (1C, C3); 130.5 $(1 \mathrm{C}, \mathrm{C} 2) ; 129.6(1 \mathrm{C}, \mathrm{C} 5) 129.0(1 \mathrm{C}, \mathrm{C} 4)$ and 123.0 (1C, C1).

\section{TEST OF THE DRUGS (MINIMUM INHIBITORY CONCENTRATION - MIC)}

To determine the MIC, the each compound was dissolved individually in a solution containing $20 \%$ dimethyl-sulfoxide (DMSO) and 80\% Tween-80. The culture medium employed was Mueller Hinton Broth (Difco). The microorganisms used in the present test were: Salmonella enteric UFPEDA 414; Klebsiella pneumoniae UFPEDA 396, Pseudomonas aeruginosas UFPEDA 416 and candida albicans UFPEDA 1007 from the culture collection of the Department of Antibiotics, Federal University of Pernambuco, all having been maintained in Mueller Hinton agar. The MIC test was carried out using the micro dilution method in micro 96-well plates containing $100 \mathrm{~mL}$ Mueller Hinton Broth, according to the procedure recommended by the Standard Clinical Laboratory Institute, CLSI (2009). The bacterial suspensions were formed in sterilized distilled water and the turbidity adjusted to 0.5 on the McFarland scale $\left(1.5 \times 10^{8} \mathrm{UFC} / \mathrm{mL}\right)$. The concentrations of all eleven compounds tested were from 1.0 to 0.00195 $\mu \mathrm{g} / \mathrm{mL}$, theantibiotic gentamicin at a concentration of $0.004 \mathrm{ug} / \mathrm{ml}$ and the antifungal amphotericin $\mathrm{B}$ at a concentration of $0.001 \mathrm{mg} / \mathrm{ml}$. These were employed as standards, having the same concentrations as recommended by CLSI (2010). Overall, 12 wells (columns) were used: In the first column, the broth alone; in the second, solvent and the broth. From columns 3 through 11, in $1.0 \mathrm{~mL}$ of the solvent, the broth was employed as follows: $1.0 \mathrm{mg} / \mathrm{mL}, 0.5 \mathrm{mg} / \mathrm{mL}, 0.25 \mathrm{mg} / \mathrm{mL}, 0.125 \mathrm{mg} / \mathrm{mL}$, $0.0625 \mathrm{mg} / \mathrm{mL}, 0.03112 \mu \mathrm{g} / \mathrm{mL}, 0.01557 \mathrm{mg} / \mathrm{mL}$, $0.07788 \mathrm{mg} / \mathrm{mL}, 0.003894 \mathrm{mg} / \mathrm{mL}$ and 0.00195 $\mathrm{mg} / \mathrm{mL}$. In the 12 th well, both broth and bacteria were added. In the second to eleventh wells, $20 \mathrm{~mL}$ of bacteria were added. The plates were incubated at $35^{\circ} \mathrm{C}$ for 24 hours. The plates with bacteria were incubated at $35^{\circ} \mathrm{C}$ for 24 hours and plates with yeast were incubated at $30^{\circ} \mathrm{C}$ for 48 hours. When the plate cultivation period ended, a reading was taken with the naked eye and afterwards a sterilized aqueous solution of resazurine $(0.1 \%)$ was added. After 4 hours of incubation, the reading was taken again. Resazurine facilitates the verification of microbial proliferation: a blue color indicates that there is no bacterial proliferation, while a red color indicates the presence of living cells in the process of proliferation. Thus, it was possible to determine the minimum concentration responsible for the inhibition of the microorganisms (Do Monte et al. 2016).

\section{MTT ASSAY}

The cytotoxicity of all compounds $\mathbf{3} \mathbf{a}-\mathbf{j}$ was measured using 3-(4,5-dimethyl-2-thiazolyl)2,5-diphenyl-2H-tetrazolium bromide (MTT). The cytotoxicity test was performed using the following cell lines: NCI-H292 (human lung muco epidermoid carcinoma cells), MCF-7 (human breast adenocarcinoma), Hep-2 (human larynx epidermoid carcinoma), HL-60 (promyelocytic leukemia cells) and HT-29 (human Colorectal Adenocarcinoma Cell Line). All cell lines were obtained from the Cell Bank of Rio de Janeiro (Rio de Janeiro, Brazil). The NCI-H292, MCF-7 and Hep-2 cells were grown in Dulbecco's modified Eagle's medium (Sigma-Aldrich, St Louis, MO), while the HL-60 cell were maintained in RPMI medium (Sigma-Aldrich, St Louis, MO). The media were supplemented with $10 \%$ fetal bovine serum (FBS) (Sigma-Aldrich, St Louis, MO) and $1 \%$ penicillin/streptomycin (Thermo Fisher Scientific, Carlsbad, CA) at $37^{\circ} \mathrm{C}$ in a $5 \% \mathrm{CO}_{2}$ atmosphere. The cells were seeded in 96-well plates and incubated for 24 hours. Subsequently, 
the ten compounds 3a-j were dissolved in DMSO (Sigma-Aldrich, St Louis, MO) (0.1\%) and added to the wells toyeilda final concentration of $500 \mu \mathrm{g} /$ $\mathrm{mL}$. The drug doxorubicin $(5 \mathrm{mg} / \mathrm{mL})$ was used as the standard. After 72 hours of incubation, 25 $\mu \mathrm{L}$ of MTT solution ( $5 \mathrm{mg} / \mathrm{mL}$ ) was added to each well, and the wells were then incubated for 3 hours. The MTT + culture medium were aspirated and $100 \mu \mathrm{L}$ of DMSO was then added. The absorbance was measured at $560 \mathrm{~nm}$ in a spectrophotometer. The experiments were performed in quadruplicate, and the percentages of inhibition were calculated with GraphPad Prism software 5.0 (DEMO). The following intensity scale was used to assess the potential of the cytotoxic samples: cytotoxic activity ( 95 to $100 \%$ inhibition), moderate cytotoxic activity (cell growth inhibition ranging from 70 to $90 \%$ ), and no cytotoxicity (growth inhibition lower than 50\%) (Freire et al. 2016, Rodrigues et al. 2014, Houghton et al. 2007, Alley et al. 1988).

\section{RESULTS AND DISCUSSION}

\section{CHEMISTRY}

All derivatives of arylamidines $\mathbf{3 a - j}$ (Figure 1) were crystalline and stable compounds with recrystallized melting points, prepared with satisfactory yield, and characterized based on their physical, analytical and spectral data. The compounds $\mathbf{3} \mathbf{b}, \mathbf{3} \mathbf{h}$ and $\mathbf{3 i}$ had been previously synthesized by the working group (Do Monte et al. 2016, Francisco 2007, Falcão et al. 2006, Melo et al. 2002) and reported in the literature. The compounds $\mathbf{3 a}, \mathbf{3 c}, \mathbf{3 d} \mathbf{d} \mathbf{g}$ and $\mathbf{3 j}$ have also been reported in the literature (Do Monte 2016).

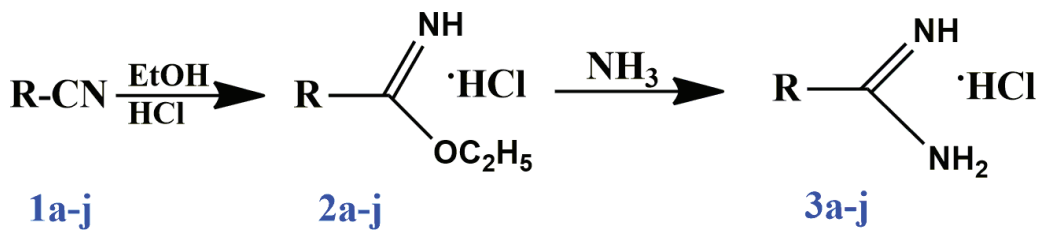

Figure 1 - Synthesis of compounds $\mathbf{3} \mathbf{a}-\mathbf{j}$ from $\mathbf{1} \mathbf{a}-\mathbf{j}$ and $\mathbf{2 a - j}$.
Syntheses of the compounds $\mathbf{3 a - j}$ are known in the literature. There is no study of $2 \mathrm{D}$ of assignments ${ }^{1} \mathrm{H}$ NMR and ${ }^{13} \mathrm{C}$ of compounds NMR spectrum. Given this, we made assignments to compound 3a using experiments IR and 2D, ${ }^{1} \mathrm{H}-{ }^{1} \mathrm{H}$ COSY (Correlation Spectroscopy), and Heteronuclear Single-Quantum Coherence (HSQC). As all compounds have one aromatic and quaternary carbons, a similar strategy was used to attribute the signals of all compounds $\mathbf{3 b}$ $\mathbf{j}$, that were characterized by their spectroscopic data, such as, IR, ${ }^{1} \mathrm{H}-\mathrm{NMR}$, and ${ }^{13} \mathrm{C}$-NMR. We observed one COSY correlation: $\delta 8.37$ with $\delta 8.17$ ppm. Therefore, there is one AA'BB' system, with coupling constant equal to $6.0 \mathrm{~Hz}$. Also, one band centered at $\delta 5.06 \mathrm{ppm}$ was observed and assigned to the hydrogen of the amino group of carbon $\mathrm{C} 7$. The 13C NMR spectrum presented 7 signals, to assign all the others, it was necessary obtain $2 \mathrm{D}$ spectra. In the HSQC spectrum, the following correlations to the AA'BB' systems were observed: $\delta_{\mathrm{H}} 8.37 \mathrm{ppm}-\delta_{\mathrm{C}} 124.4 \mathrm{ppm} ; \delta_{\mathrm{H}} 8.17 \mathrm{ppm}-\delta_{\mathrm{C}} 134.2$ But a complete assignment was only possible using the HMBC experiment, with which the correlations were observed and the attributions made. So, $\delta_{\mathrm{H}}$ $8.37 \mathrm{ppm}$ (H2 and H6 nuclei) correlates $\delta_{\mathrm{C}} 150.0$ ppm (C1 nucleus), $133.3 \mathrm{ppm}$ (C4 nucleus) and $\delta_{\mathrm{C}} 124.4 \mathrm{ppm}$ (C3 and $\mathrm{C} 6$ nuclei) and 8.17 (H3 and $\mathrm{H} 5$ nuclei) correlates $\delta_{\mathrm{C}} 150.0 \mathrm{ppm}$ (C1 nucleus), 133.3 ppm (C4 nucleus), 134.2 ppm (C2 and C6 nuclei) and $164.3 \mathrm{ppm}$ (C7 nucleus).

A similar strategy was used to attribute the signals of the $o, m$, and $p$-arylamidines groups of all compounds $\mathbf{3 b} \mathbf{b} \mathbf{j}$.

$$
\begin{gathered}
\mathrm{R}:-4 \mathrm{NO}_{2} \mathrm{Ph}(\mathbf{3 a}) ;-4 \mathrm{OMePh}(\mathbf{3 b}) ; \\
-4 \mathrm{MePh}(\mathbf{3 c}) ;-4 \mathrm{NC}_{2} \mathrm{H}_{6} \mathrm{Ph}(\mathbf{3 d}) ; \\
4 \mathrm{NH}_{2} \mathrm{Ph}(\mathbf{3 e}) ;-4 \mathrm{CF}_{3} \mathrm{Ph}(\mathbf{3 f}) ; \\
-\mathrm{BrCH}_{2} \mathrm{Ph}(\mathbf{3 g}) ;-\mathrm{ClPh}(\mathbf{3 h}) ; \\
-2,4 \mathrm{ClPh}(3 \mathbf{3}) ; 3 \mathrm{ClPh}(3 \mathbf{j})
\end{gathered}
$$




\section{ANTIMICROBIAL ACTIVITY}

Compounds 3a-j were screened for antimicrobial activity. (Mueller Hinton Broth - Difco) from $0.00195 \mathrm{mg} / \mathrm{mL}$ to $1.0 \mathrm{mg} / \mathrm{mL}$ (Table I) was used as the nutrient. We used the antibiotic gentamicin concentration of $0.004 \mathrm{mg} / \mathrm{ml}$, and the antifungal Amphotericin B in a concentration of $1 \mathrm{ug} / \mathrm{ml}$ as the controls. The compounds $\mathbf{3 f}, \mathbf{3 i}$ and $\mathbf{3 g}$ were tested for their activities against Gram-negative bacteria (Klebsiella pneumoniae, Salmonella enteric and
Pseudomonas aeruginosa) and against yeast (Candida albicans). The results revealed that most of the synthesized compounds showed inhibition against the tested microorganisms, as shown in Table I. The compounds $\mathbf{3 f}$ and $\mathbf{3 g}$ were moderately active with a large bacterial spectrum. Compound $3 \mathbf{i}$ was only moderately active against pseudomona aeruginosa. None of the above compounds showed better results than the controls tested.

TABLE I

Antibacterial property of tested compounds 3a-j, "MIC $=1.0-0.0095 \mathrm{mg} / \mathrm{mL}$.

\begin{tabular}{|c|c|c|c|c|c|}
\hline Compounds & $\mathbf{R}$ & $\begin{array}{c}\text { Klebsiella } \\
\text { pneumoniae }\end{array}$ & $\begin{array}{c}\text { Salmonella } \\
\text { enteric }\end{array}$ & $\begin{array}{c}\text { Pseudomona } \\
\text { aeruginosa }\end{array}$ & C. Albicans \\
\hline $3 a$ & p-NO2 & - & - & - & - \\
\hline $\mathbf{3 b}$ & $\mathrm{p}-\mathrm{CH} 3 \mathrm{O}$ & - & - & - & - \\
\hline $3 c$ & $\mathrm{p}-\mathrm{CH} 3$ & - & - & - & - \\
\hline $3 d$ & $\mathrm{p}-(\mathrm{CH} 3) 2 \mathrm{~N}$ & - & - & - & - \\
\hline $3 e$ & $\mathrm{p}-\mathrm{NH} 2$ & - & - & - & - \\
\hline $3 f$ & p- CF3 & 1.0 & 1.0 & 0.5 & 0.5 \\
\hline $3 g$ & $\mathrm{p}-\mathrm{CH} 2 \mathrm{Br}$ & 1.0 & 1.0 & 0.5 & 0.5 \\
\hline $3 \mathrm{~h}$ & $\mathrm{p}-\mathrm{Cl}$ & - & - & - & - \\
\hline $3 \mathbf{i}$ & $\mathrm{o}, \mathrm{p}-\mathrm{Cl}$ & - & - & 1.0 & - \\
\hline $3 \mathbf{j}$ & $\mathrm{m}-\mathrm{Cl}$ & - & - & - & - \\
\hline
\end{tabular}

TABLE II

Cytotoxic Activity of Compounds 3a-j against Cell Lines.

\begin{tabular}{cccccc}
\hline \multicolumn{1}{c}{ Compounds } & HEp-2 & HL-60 & HT-29 & MCF-7 & NCIH-292 \\
\hline 3a & $10.4(8.7-11.9)$ & $>25 \mu \mathrm{g} / \mathrm{mL}$ & $36.0(19.8-65.4)$ & $5.8(5.4-6.2)$ & $5.1(4.7-5.7)$ \\
3b & $11.9(8.7-16.2)$ & $>25 \mu \mathrm{g} / \mathrm{mL}$ & $>25 \mu \mathrm{g} / \mathrm{mL}$ & $17.9(15.0-21.4)$ & $6.0(5.3-6.8)$ \\
3c & $13.9(12.4-15.7)$ & $7.1(6.3-8.1)$ & $24.8(22.2-27.6)$ & $42.8(20.6-89.2)$ & $6.0(5.6-6.3)$ \\
3d & $>25 \mu \mathrm{g} / \mathrm{mL}$ & $2.0(1.6-2.4)$ & $25.4(23.5-27.6)$ & $8.8(6.9-11.1)$ & $>25 \mu \mathrm{g} / \mathrm{mL}$ \\
3e & $>25 \mu \mathrm{g} / \mathrm{mL}$ & $>25 \mu \mathrm{g} / \mathrm{mL}$ & $>25 \mu \mathrm{g} / \mathrm{mL}$ & $>25 \mu \mathrm{g} / \mathrm{mL}$ & $>25 \mu \mathrm{g} / \mathrm{mL}$ \\
$\mathbf{3 f}$ & $1.3(1.0-1.7)$ & $16.7(12.5-22.3)$ & & $5.07(3.7-6.8)$ & - \\
3g & $30.7(20.4-46.1)$ & $>25 \mu \mathrm{g} / \mathrm{mL}$ & $>25 \mu \mathrm{g} / \mathrm{mL}$ & $22.1(20.0-24.4)$ & - \\
3h & $26.3(19.6-35.2)$ & $>25 \mu \mathrm{g} / \mathrm{mL}$ & $>25 \mu \mathrm{g} / \mathrm{mL}$ & $27.7(19.8-38.7)$ & - \\
3i & $21.6(20.4-22.9)$ & $5.4(4.6-6.3)$ & $26.5(21.1-33.2)$ & $28.3(19.8-41.8)$ & - \\
3j & $>25 \mu \mathrm{g} / \mathrm{mL}$ & $>25 \mu \mathrm{g} / \mathrm{mL}$ & $>25 \mu \mathrm{g} / \mathrm{mL}$ & $6.4(5.5-7.3)$ & - \\
Doxorubicin & $0.7(0.3-1.4)$ & $0.06(0.05-0.08)$ & $0.4(0.3-0.5)$ & $0.11(0.08-0.15)$ & $0.01(0.04-0.3)$ \\
\hline
\end{tabular}


TABLE III

Percentage of cell growth inhibition (\%) in $25 \mu \mathrm{g} / \mathrm{mL}$.

\begin{tabular}{ccccccccccc}
\hline Compounds & HEp-2 & EM & HT-29 & EM & $\begin{array}{c}\text { HL- } \\
\mathbf{6 0}\end{array}$ & EM & MCF-7 & EM & NCIH-292 & EM \\
\hline 3a & $>100$ & 1.4 & 94.9 & 0.1 & 64.5 & 2.4 & $>100$ & 0.5 & 86.5 & 5.4 \\
3b & 93.4 & 1.6 & 54.5 & 1.7 & 71.6 & 0.4 & 98.4 & 0.9 & $>100$ & 0.7 \\
3c & 89.5 & 6.2 & 88.1 & 1.3 & $>100$ & 0.1 & 80.4 & 0.7 & $>100$ & 1.1 \\
3d & 48.9 & 2.4 & 94.8 & 1.4 & $>100$ & 0.0 & 99.1 & 0.2 & 60.1 & 0.9 \\
3e & $>100$ & 3.0 & 41.7 & 1.2 & 57.3 & 2.3 & 96.0 & 0.4 & $>100$ & 0.8 \\
3f & $>100$ & 1.6 & 79.9 & 1.3 & 87.3 & 4.0 & 83.6 & 1.1 & $>100$ & 0.5 \\
3g & 99.3 & 0.6 & 70.5 & 5.2 & 55.4 & 0.3 & 98.5 & 1.9 & 98.9 & 0.4 \\
3h & NA & NA & 38.1 & 1.1 & 46.2 & 2.3 & 71.0 & 0.6 & 59.4 & 1.7 \\
3i & 81.0 & 6.3 & 88.2 & 1.3 & $>100$ & 0.1 & 80.6 & 2.0 & 93.8 & 3.0 \\
3j & NA & NA & 37.0 & 1.8 & 23.2 & 0.2 & 94.6 & 1.0 & 81.2 & 2.0 \\
Doxorubicin & 51.6 & 3.7 & 92.9 & 0.6 & $>100$ & 0.9 & 86.2 & 0.5 & 90.9 & 0.4 \\
\hline
\end{tabular}

NA: No activity; EM: Mean error.

\section{CYTOTOXICITY EVALUATION}

The cellular cytotoxicity of the compounds $\mathbf{3 a - j}$ was verified by the MTT assay. In the MTT assay, the $\mathbf{3 a - d}, \mathbf{3 f}, \mathbf{3 g}, \mathbf{3 i}$ and $\mathbf{3 j}$ samples were non-toxic at a concentration of $\mathrm{IC}_{50}$ low of $25 \mu \mathrm{g} / \mathrm{mL}$ (Table II), since the cell inhibition was below standard (Table III). Compounds 3d and $\mathbf{3 f}$ were the most effective derivatives against HL-60 and HEp-2 cells, respectively, with an $\mathrm{IC}_{50}$ value low of $2 \mu \mathrm{g} /$ $\mathrm{mL}$, making them good candidates for use in cancer treatment because of their low toxicity against cells.

\section{CONCLUSIONS}

We synthesized ten derivatives of the arylamines 3a-j in their crystalline state. All compounds were characterized by their infrared ${ }^{1} \mathrm{H}-\mathrm{NMR}$ and ${ }^{13} \mathrm{C}-\mathrm{NMR}$ spectra and a $2 \mathrm{D}$ spectroscopy study was performed. Bioassays of all compounds were carried out and we were able to determine the Minimum Inhibition Concentration (MIC) against Gram-negative bacteria and yeast. The compounds 3f and 3g were moderately active with a large bacterial spectrum; 3i was only moderately active against pseudomona aeruginosa. All cells $\left(\mathrm{ED}_{50}=\right.$ $25 \mu / \mathrm{mL}$ ) showed low toxicity towards compounds 3a-d, 3f, 3g, 3i and $\mathbf{3 j}$. The best results were for compounds $\mathbf{3 d}$ and $\mathbf{3 f}$. But, only compounds $\mathbf{3 f}, \mathbf{3 g}$ and $\mathbf{3 i}$ are good candidates for microbial infections and cancer treatment because of their high toxicity.

\section{REFERENCES}

ADIYALA PR, CHANDRASEKHAR D, KAPURE JS, REDDY CN AND MAURYA RA. 2014. Synthesis of $\alpha$-amino amidines through molecular iodine-catalyzed three-component coupling of isocyanides, aldehydes and amines. Beilstein J Org Chem 10: 2065-2070.

ALLEY MC, SCUDIERE DA, MONKS A, HURSEY ML CZERWINSKI MJ, FINE DL, ABBOTT BJ, MAYO JG, SHOEMAKER RH AND BOYD MR. 1988. Feasibility of drug screening with panels of human tumor cell lines using a microculture tetrazolium assay. Cancer Res 48: 589-601.

ANDREWS B AND MANSUR A. 2014. Synthesis and characterization of pyrimidine bearing 1,2,4-triazole derivatives and their potential antibacterial action. Der Pharma Chemica 6(1): 162-169.

ARAFA RK, BRUN R, WENZLER T, TANIOUS FA, WILSON WD, STEPHENS CE AND BOYKIN DW. 2005. Synthesis, DNA Affinity, and Antiprotozoal Activity of Fused Ring Dicationic Compounds and Their Prodrugs. J Med Chem 48: 5480-5488. 
ASANO T, YOSHIKAWA T, NAKAMURA H, UEHARA Y AND YAMAMOTO Y. 2004. Synthesis and biological evaluation of benzamides and benzamidines: structural requirement of a pyrimidine ring for inhibition of EGFR tyrosine kinase. Bioorg Med Chem Lett 14: 2299-2302.

CLSI - CLINICAL LABORATORY STANDARDS INSTITUTE. 2009. Methods for dilution antimicrobial susceptibility test for bacteria that grow aerobically, $7^{\text {th }}$ ed., Approved standard M7-A8. CLSI, Wayne, PA.

CLSI - CLINICAL LABORATORY STANDARDS INSTITUTE. 2010. Performance standards for antimicrobial susceptibility testing: twentieth Informational Supplement. Approved M100-S20. CLSI, Wayne, PA.

DE MELO SJ, SANTOS LC, FALCÃO EPS, SRIVASTAVA RM AND LUU-DUC C. 2002. Synthesis of new 4-amino5-ciano-2,6-diarylpyrimidines. J Chem Res 5: 216-217.

DO MONTE SZ, MONTEIRO MRL, BORBA CBA, GUSMÃO NB, FALCÃO EPS, SILVA RO, SRIVASTAVA RM AND DE MELO SJJ. 2016. Synthesis of 4-amino-2,6diaryl-5-cyanopyrimidines as antimicrobial agentes. Synth Commun 46(11): 983-991.

DO MONTE ZSD. 2016. Pirimidinas: de Potenciais Fármacos a Marcadores Fluorescentes. Tese (Doutorado em Ciências Farmacêuticas). Universidade Federal de Pernambuco.

FALCÃO EPS, DE MELO SJ, SRIVASTAVA RM, CATANHO MTJA AND DO NASCIMENTO SC. 2006. Synthesis and antiinflammatory activity of 4-amino-2-aryl-5-cyano-6$\{3-$ and 4-(Nphthalimidophenyl) $\}$ pyrimidines. Eur J Med Chem 41: 276-282.

FRANCISCO JBMJ. 2007. Síntese de Glicopiranosídeos 2,3-insaturados acoplados a heterocíclicos em C-4, Funcionalização da posição C-5 dos glicoheteroíclos 4'-(5-halo-uracil-1-il) através de reações catalisadas por coplexos de $\operatorname{Pd}(0)$. Tese (Doutorado em Ciências Biológicas). Universidade Federal de Pernambuco.

FREIRE PLL, ALBUQUERQUE AJR, FARIAS IAP, DA SILVA TG, AGUIAR JS, GALEMBECK A, FLORES MAP, SAMPAIO FC, STAMFORD TCM AND ROSENBLATT A. 2016. Antimicrobial and cytotoxicity evaluation of colloidal chitosan - silver nanoparticles fluoride nanocomposites. J Biolog Macromol 93: 896-903.
HOUGHTON P, FANG R, TECHATANAWAT I, STEVENTON G, HYLANDS PJ AND LEE CC. 2007. The sulphorhodamine (SRB) assay and other approaches to testing plant extracts and derived compounds for activities related to reputed anticancer activity. Methods 42: 377-387.

MAKAROV VA, RIABOVA O, GRAMIK VG, AHSE H, STELZNER A, WUTZLER P AND SCHMIDTKE M. 2005. Anti-coxsackoevirus B3 activity of 2-amino-3nitropyrazolo[1,5- $\alpha]$ pyrimidines and their analogs. Bioorg Med Chem Lett 15: 37-39.

MARZANO C ET AL. 2010. A New Class of Antitumor transAmine-Amidine-Pt(II) Cationic Complexes: Influence of Chemical Structure and Solvent on in Vitro and in Vivo Tumor Cell Proliferation. J Med Chem 53: 6210-6227.

NATARAJAN S, SUSAIMANICKAM AA AND SAMRAJ S. 2014. Synthesis, characterization and anti microbial screening of novel 1-pyrazole acid 2,4,5-tri aryl imidazole derivatives. J Chem Tech Res 6(2): 1220-1227.

PIZZUTI L. 2005. Síntese de 4-(fur-2-il)- e (tien-2-il) pirimidinas a partir de $\beta$-alcoxiviniltrifluormetil cetonas. Dissertação (Mestrado em Química). Universidade Federal de Santa Maria. (Unpublished).

RODRIGUES FA, BOMFIM S, CAVALCANTI BC, PESSOA C, GONCALVES RS, WARDELL JL, WARDELL SM AND SOUZA MV. 2014. Mefloquine-Oxazolidine Derivatives: A New Class of Anticancer Agents. Chem Biol Drug Des 83: 126-131.

SAMUEL NS, ATHINA G, DOMENICO S, RUZANNA GP, IRINA AD, IVETTA MN, ASMIK HÁ AND ANUSH AH. 2016. Pyridofuropyrrolo[1,2-a]pyrimidines and pyridofuropyrimido[1,2-a]azepines: new chemical entities (NCE) with anticonvulsive and psychotropic properties. RSC Adv 6: 32234-32244.

TAHGHIGHI A, MARZNAKI FR, KOBARFARD F, DASTMALCHI S, MOJARRAD JS, RAZMI S, ARDESTANI SK, EMAMI S, SHAFIEE A AND FOROUMADI A. 2011. Synthesis and antileishmanialactivity of novel 5-(5-nitrofuran2-y1)-1,3,4-thiadiazoles with piperazinyl-linked benzamidinesubstituents. Eur J Med Chem 46(6): 26022608. 